\title{
The Capability to Predict the Behaviors of the Students Enrolled in Jordanian Universities Through Their Aesthetic Values
}

\begin{abstract}
Rawan Fayyad Za'al Fallouh Prof. Mohammed Amin Al-Qudah
The University of Jordan

Abstract

The present study aimed to explore the extent of adopting aesthetic values and doing good behaviors by the students enrolled in Jordanian universities from the perspective of faculty members. It aimed to explore the capability to predict the behaviors of the students enrolled in Jordanian universities through their aesthetic values. A descriptive analytical approach was adopted. In addition, a correlative approach was adopted too. A questionnaire was used for collecting data from 364 female and male faculty members. Those faculty members were selected from (private and public) Jordanian universities. The questionnaire sheds a light on four areas; (the social, behavioral, psychological and affective) areas. It was found that the extent of adopting aesthetic values by the students enrolled in Jordanian universities is moderate from the perspective of faculty members. It was found that the extent of doing good behaviors by the students enrolled in Jordanian universities is moderate from the perspective of faculty members. That means that additional efforts must be exerted by decision makers and educators in order to promote good behaviors and aesthetic values among students in Jordanian universities. It was found that there is a strong correlative relationship between the aesthetic values and the behaviors of the students enrolled in Jordanian universities. That is because the correlative coefficient value is 0.84 and the value of the total sum of squares is 0.68 . That means that $68 \%$ of the changes in the students' behaviors are attributed to the aesthetic values. That means that the behaviors of the students enrolled in Jordanian universities can be significantly predicted through their aesthetic values. The researchers of the present study recommend carrying out suitable educational measures in the aim of promoting aesthetic values among the students enrolled in Jordanian universities
\end{abstract}

Keywords: Aesthetic values, behavior, students.

DOI: $10.7176 / \mathrm{JEP} / 11-4-11$

Publication date: February $29^{\text {th }} 2020$

\section{Introduction}

Education aims at promoting a set of values among the members of a society. It aims at improving people's behaviors in accordance with the dominant values in the concerned society. It aims at transferring the society's heritage from one generation to another. It aims at promoting positive aspirations among people. It aims at encouraging people to do good behaviors and avoid bad behaviors. It aims at promoting knowledge among people about the way of encouraging others to do good behaviors.

In the light of the aforementioned information, education plays a very significant role in making changes to society. There are several educational methods, instruments, goals and mechanisms used by educators. The use of educational mechanisms aims at making several major changes in society in various aspects; the economic, social, and cultural aspects. It also aims at making several major changes to the prevalent ethical, religious and aesthetic values in society. Thus, the reality of a specific society reflects the role of education in that society. It also reflects the impact of education on that society.

Adopting values by one and society is something important. Therefore, it is important to instill values within one. For instance, values shall affect the way one deals with others, situations and things. It shall affect the way one behaves and acts. As for the values adopted by a group, they shall be manifested through the goals, activities and relationships of that group. It should be noted that each society has its own values (Ben Tarif and Al-Qudah, 2019 and Fawzi, 2007).

Spranger (1921) and Hanel (2016) classify values into six types; scientific (theoretical), economic, social, religious, aesthetic, and political values. The scientific values govern the way one discovers facts. The economic values govern the way one acquires fortune. The social values govern the way one interacts socially with others. The religious values govern one's relationship with God. The political values govern the way one utilizes his/her political power. The aesthetic values govern the way one sees beauty and creativity in things (Bakoush, 2017).

Aesthetic education is part of the general ideology. It enables one to form his/her own opinions about the works of art. It aims at promoting values among people. It aims at regulating one's behavior and shaping one's beliefs. It aims at developing one in affective areas (Hatahet \& Alqudah, 2016, Al-Shloul, 2007). It participates in developing one in emotional, social, and cognitive areas. It also participates in developing one's artistic abilities. It enriches one's knowledge about the works of art and the value of art. Thus, it shall make one value art. It also participates in achieving personal development (Kroflič, 2007). It participates in developing one's capability to experience, observe, evaluate and create beautiful things. In fact, it improves one's ability to experience and perceive aesthetic qualities. Through experiencing such qualities, one shall become capable of 
experiencing feelings of excitement, optimism, and joy when seeing works of art. Experiencing such qualities shall affect one emotionally. Aesthetic education shall promote creativity among students (Trstenjak, 1981, Denac et al., 2011).

It should be noted that teachers in all courses must promote aesthetic values among school students. That applies whether the teachers are teaching math, history or etc.. (Denac et al., 2011). Aesthetic values are considered significant values that students must adopt (Zamel, 2015). They make students love nature and see beauty in things. They instill a sense of humor within one. They make one love trips, and adventures. They encourage one to express himself/herself. They encourage one to meet his/her physical needs (Abu Zeid, and AlZyood, 2007). The one who has aesthetic values is the one who seeks achieving balance between things. He seeks interpreting things from a logical perspective. The one who has economic values seeks utilizing knowledge to generate money. The one who has social values seeks providing care and attention to others. The one with political values seeks influencing others and becoming famous. The one with religious values is concerned with spiritual and holy things (Zaman and Muhammad, 2012). Aesthetic values are not detached from other values. In facts, they are connected with other values.

Education aims at developing one in various areas. Such areas include aesthetic areas. Developing one in the aesthetic areas shall participate in making one's personality well developed in all areas (Orsinger, 2014). The one who has the latter personality shall seek achieving a balance between his physical and intellectual needs (AlHammad \& Al-Qudah, 2019, Al-Qudah, 2006, Al-Hailat et al., 2008, Sheler, 1991).

Various educational institutions- including universities- seek developing students' personalities in various aspects. That is done through providing students with knowledge and shaping their behavior. It is done through teaching students how to think right. Thinking in a right manner shall make positive changes to the values adopted by students. It shall develop students in intellectual and psychological areas. It shall make students enjoy much security and safety. It shall lead to promote fairness in society. It shall enable the society to advance and develop in various areas. It should be noted that promoting values in society shall enable society to achieve development and advancement (Al-Tamimi \& Al-Qudah, 2019, Jbara and Al-Qudah, 2018; Al-Turk and AlQudah, 2017; and Al-Omari, 2015).

Young people play a significant role in society. Therefore, it is very important to explore the values adopted by young people. In addition, it is challenging to instill positive values within young people, especially within the secondary school students and the university students (Asayesh and Bahramizadeh, 2011). Several studies aimed to shed a light on the values adopted by university students. They aimed to shed a light on this subject because the age category of those students is very important. It's because it is very important to explore the extent of awareness among young people about the significance of values. Having a high awareness in this regard shall positively affect young people and society (Al-Harbi, 2018; and Al-Qudah, 2017).

Several studies about values suggest that the period of receiving higher education has a major impact on students. They suggest that this period plays a significant role in promoting positive values among students. This period is important because university students has education needs that must be met. Such needs are represented in instilling positive values within them. Instilling positive values within them shall enable them to have a good future after graduation (Al-Qudah \& Al-Zboon \& Al-Ashqar, 2016; Al-Qudah, 2017, Al-Omari, 2010).

Several educational studies suggest that university and school curricula do not provide adequate attention to aesthetic values. Several educational studies suggest that the makers of educational decisions do not provide adequate attention to aesthetic values. Therefore, there isn't adequate attention provided to the works of art and aesthetic values. Therefore, more studies must be conducted about the works of art and aesthetic values. Such studies must emphasize the need for providing more attention to these issues (Malkawi, \&Al-Qudah, 2018, Abu Naser, 1996).

In the light of the aforementioned information, it can be concluded that it is very important to conduct studies about aesthetic values. There is a need to conduct such studies, because societies have been experiencing rapid changes. There is a need to conduct such studies because it has become essential for one to adjust himself/herself with the surrounding environment. Such adjustment shall enable one to handle the surrounding challenges.

Young people -especially university students- shall become responsible for making a family that adopt positive values. They shall become responsible for developing the future of the nation. Furthermore, university students represent the greatest percentage of young people in the Jordanian society. Therefore, the present study aimed to explore the extent of adopting aesthetic values by the students enrolled in Jordanian universities from the perspective of faculty members. It aimed to explore the capability to predict the behaviors of the students enrolled in Jordanian universities through their aesthetic values. It is important to conduct the present study due to the significance of the aesthetic values. It is important to conduct the present study due to the major impacts of such values on the future of university students. 
Statement of the Problem and the Study's Questions:

Educational institutions today do not provide adequate attention to the development of values in general and aesthetic values in particular. They are concerned in delivering knowledge to students through using the spoonfeeding teaching method. The use of this method led to having people who aren't capable to see the aesthetic aspects of things. It negatively affected people's behaviors. It led to the spread of negative phenomena in societies. It make people give up some important values. Aesthetic education makes people have a conscience that regulates the way in which they behave. Therefore, it has become necessary to develop people's aesthetic values. It has become necessary to instill aesthetic values within people. That shall make people capable of handling future challenges.

In the light of that, the present study aimed to explore the capability to predict the behaviors of the students enrolled in Jordanian universities through their aesthetic values. It aimed to explore that from the perspective of faculty members. To be more specific, it aimed to answer the following questions:

Q.1. What is the extent of adopting aesthetic values by the students enrolled in Jordanian universities from the perspective of faculty members?

Q.2. What is the extent of doing good behaviors by the students enrolled in Jordanian universities from the perspective of faculty members?

Q.3. What is the extent of capability to predict the behaviors of the students enrolled in Jordanian universities through their aesthetic values?

\section{The Study's Objectives:}

The present study aimed to explore the extent of adopting aesthetic values and doing good behaviors by the students enrolled in Jordanian universities from the perspective of faculty members. It aimed to explore the capability to predict the behaviors of the students enrolled in Jordanian universities through their aesthetic values.

\section{The Study's Significance:}

The present study is significant because it aimed to explore the extent of adopting aesthetic values by the students enrolled in Jordanian universities. It is significant because it aimed to propose an educational role for Jordanian universities in order to promote aesthetic values among students. To be specific, it is significant because:

1- It aimed to explore the extent of adopting aesthetic values by the students enrolled in Jordanian universities. Identifying such information shall enable Jordanian universities to promote positive values among students and fight against the negative values that are spreading among students.

2- It provides decision makers in universities with important information that shall enable those decision makers to make effective educational decisions and develop programs that aim at promoting positive values among students. Such programs shall make students do good behaviors.

3- It provides a theoretical framework for the researchers who want to conduct studies about aesthetic values. This framework is important because there aren't many studies that shed a light on the aesthetic values. The present study aimed to shed a light on the capability to predict the behaviors of the students enrolled in Jordanian universities through their aesthetic values. That shall encourage researchers to conduct studies about aesthetic values and the role of such values in making people do good behaviors. There is a need to explore the latter capability due to the significance of aesthetic values. Through conducting the present study, decision makers can develop methods for promoting aesthetic values among people in society. Such promotion shall positively affect people and society

\section{Definition of Terms:}

- The theoretical definition of values:

Values refer to a group of principles, measurements and indicators that regulate one's attitudes, beliefs, and ideas. They regulate one's ambitions, behaviors, and aspirations. They regulate one's stand on issues. (AlJallad, 2005).

- The theoretical definition of aesthetic values:

- Aesthetic values refer to a set of attributes that are related to body, and fitness. They refer to seeing beauty in things and having love for nature, adventure, and trips. They refer to the desire to achieve excellence. They refer to having a sense of humor and expressing one's self (Abu Zeid, and Al-Zyood, 2007).

- The operational definition of aesthetic values:

Aesthetic values refer to a set of principles and standards that are related to the way in which the student perceives himself and his desires, and ambitions. They are developed through providing student with aesthetic education. This education is provided at home and educational institutions. They are developed through interacting with the surrounding environment (i.e. people and tangible things). They are measured through the 
study's instrument.

\section{The Study's Limits:}

The present study was conducted during the first semester of the academic year of 2019/2020. It was conducted in private and public Jordanian studies through sampling faculty members.

\section{Previous Studies:}

The researchers reviewed several relevant studies. Those studies are presented below from the oldest ones to the newest ones:

Al-Jahni (2003) aimed to explore the way of developing students' aesthetic values from an Islamic perspective. She aimed to explore that from the perspective of the experts in education in Saudi Arabia. She adopted a descriptive approach and developed a questionnaire. She found that such development must begin since childhood. She found that instilling such values occurs through seeing practical applications.

Bukhari (2006) aimed to explore the meaning and principles of aesthetic education under the Islamic and western ideologies. He used an inductive approach. He found that human beings has been capable to see beauty in things since their creation. That is because god instilled the capability within humans. However, aesthetic education aims to develop this capability. The latter researcher found that Islam aims at promoting compliance with values and prohibiting the commitment of any indecent act.

Mercader (2006) aimed to shed a light on ethical values among university students. He aimed to identify the prevalent values among students from the perspectives of students and others. He aimed to identify the benefits gained from adopting ethical values. The sample consists from 220 female and male university students who were selected from 11 courses. These courses are taught at the global languages department at Florida University. Those students represent the whole population of the study. The questionnaire consists from 10 items. These items aim at shedding a light on 28 ethical values. Such values include: respect, kindness, selfmotivation, trust, integrity, tolerance, excitement, humbleness, communication, friendship, and decision making. It was found that there are several values that are prevalent among students, such as: integrity, self-respect, loyalty, trust, showing respect for family, working hard, and handling responsibilities.

Abu Zeid, and Al-Zyood (2007) aimed to explore the (cognitive, social, ethical, aesthetic, religious, economic and political) values that are adopted by secondary school students in Amman. They aimed to explore that from the perspective of the students themselves. They aimed to explore whether there are statistically significant differences between the respondents' in terms of the extent of adopting those values which can be attributed to gender, grade, family income and the directorate that the school is affiliated with. Data was collected through using a questionnaire. The questionnaire forms were distributed to a random sample that consists from 1100 female and male secondary school students. It was found that the extent of adopting these values jointly is high. It was found that the political values are ranked first, followed by the religious, ethical, aesthetic, social, economic and cognitive values respectively. It was found that there are statistically significant differences between the respondents' in terms of the extent of adopting those values which can be attributed to grade, family income and the directorate that the school is affiliated with. It was found that there isn't any statistically significant difference between the respondents' in terms of the extent of adopting those values which can be attributed to gender.

Zaman and Muhammad (2012) aimed to explore the differences between the students enrolled in private universities and the students enrolled in public universities in Bangladesh in terms of the personal (theoretical, economic, aesthetic, religious, political and social) values. The sample consists from 104 students; 52 ones from public universities and 52 ones from private universities. All the respondents are males. Data was collected through a questionnaire. It was found that there isn't any statistically significant difference between the respondents' in terms of the extent of adopting theoretical, aesthetic, and religious values. It was found that there are any statistically significant differences between the respondents' in terms of the extent of adopting economic, social and political values. It was found that the extent of adopting economic, social and political values by the students enrolled in public universities is higher than the counterpart extent of adoption by the students enrolled in private universities.

Denac (2014) aimed to explore the significance of aesthetic education in school. He reviewed several studies to meet the study's goals and adopted a theoretical approach. He found that the latter education plays a significant role in developing one's personality. He also found that the latter education plays a significant role in developing one's professional knowledge and skills. He concluded that providing aesthetic education at schools shall enable students to enjoy art and beauty. Therefore, teachers must encourage students to see, and notice beauty in art and nature (Denac, 2014)

Sharma (2015) aimed to explore whether there are differences between BA students in terms of the extent of adopting aesthetic, economic, and political values. The sample consists from 300 female and male students. 150 ones of them were selected from the faculty of fine arts and 150 ones of them were selected from the faculty of business administration in Gujarat University in India. A questionnaire was used for data collection. It was 
found that the extent of adopting aesthetic values by the ones enrolled in the faculty of fine arts is higher than the counterpart extent of adoption by the ones enrolled in the faculty of business administration. It was found that the extent of adopting economic values by the ones enrolled in the faculty of business administration is higher than the counterpart extent of adoption by the ones enrolled in the faculty of fine arts. It was found that there isn't any statistically significant difference between the respondents' extent of adopting political values which can be attributed to the type of faculty. It was found that there is a statistically significant difference between the respondents' extent of adopting political values which can be attributed to gender for the favor of males.

Bakoush (2017) aimed to explore the impact of the social change that occurred to the Algerian society on the social values adopted by university students. These values are: (economic, religious, ethical, political, theoretical, and aesthetic values). The population consists from all the students enrolled in six Algerian universities; (Al-Wadi University, Constantine 2 University, Msila University, Djilai Bounaana University, Saida University, and Mustafa Stmboli University). 100 students from each university were sampled. As for the total sample, it consists from 600 students. A sixty item questionnaire was used for data collection. It was found that the social change that occurred to the Algerian society has a significant impact on social values in general. It was found that the social change that occurred to the Algerian society has a significant impact on economic, religious, ethical, political, theoretical, and aesthetic values adopted by university students.

Jardim et al. (2018) aimed to explore the extent of adopting ethical and religious values by the students enrolled in Madeira University and Fortaleza University. They aimed to explore the perceptions of those students for life. The sample consists from 605 students; 225 ones enrolled at Madeira University and 380 ones enrolled at Fortaleza University. Data was collected through a questionnaire. It was found that the extent of adopting ethical and religious values by the respondents is high. For instance, the respondents reject racial discrimination, and desire to achieve social justice. It was found that the respondents believe in God and after life.

\section{Comments on the Aforementioned Studies:}

Most of the aforementioned studies are conducted outside Jordan. There is only one study conducted in Jordan. This study is conducted by Abu Zeid, and Al-Zyood (2007). The latter study shed a light on several values, including the aesthetic values.

The present study is different from the aforementioned studies. That is because the present study aimed to shed a light on the extent of adopting aesthetic values and doing good behaviors by the students enrolled in Jordanian universities from the perspective of faculty members. It's because the present study aimed to explore capability to predict the behaviors of the students enrolled in Jordanian universities through their aesthetic values. As far as the researchers know, the present study is the first study that sheds a light on this subject in Jordan. It should be noted that the aforementioned studies assisted the researchers of the present study in developing the instrument, writing the theoretical framework and interpreting the results.

\section{The Study's Methodology:}

The researchers adopted a descriptive analytical approach and a survey-based approach. They also adopted a correlative approach. Through adopting these approaches, the researchers collected data through using a questionnaire. It is adopted for providing a sensory description for things and items. It can be adopted to determine whether the sensory attributes of something are deemed accepted or not. It may be adopted by researchers to explore specific variables and their dimensions \& constituents (Lawless and Heymann, 1999).

\section{The Study's Population:}

The study's population consists from all the faculty members who work at (private and public) Jordanian universities. Based on the statistics issued by the Ministry of Scientific Research and Higher Education for the academic year (2018/2019), the population consists from 10276 faculty members.

\section{The Study's Sample}

The study's sample was selected through using the random sample. It consists from 370 faculty members. 364 forms were retrieved and considered valid for analysis. Thus, the final sample consists from 364 faculty members.

\section{The Study's Instrument}

To meet the study's goals, the researchers developed the study's instrument based on the relevant literature and previous studies. Such studies include the ones conducted by Zaman and Muhammad (2012), and Sharma (2015). The researchers developed the study's instrument based on the experts' opinions. The study's instrument sheds a light on four areas; (the social, behavioral, psychological and affective) areas.

\section{Reliability and Validity of the Instrument}


The researchers checked the face validity of the questionnaire. That was done through passing the preliminary version of the questionnaire to a panel of experts. Those experts are faculty members who work at Jordanian universities. Those experts were asked to assess the questionnaire and provide their opinions about it in terms of language, clarity and relevancy. In the light of the experts' opinions, several modifications were made. Such modifications are represented in paraphrasing some statements. To measure the reliability of the questionnaire, Cronbach Alpha coefficient value was calculated. This value is 0.96 . That means that the questionnaire is reliable.

\section{The Study's Results and Discussion:}

Results and Discussion related to the first question:

Q.1. What is the extent of adopting aesthetic values by the students enrolled in Jordanian universities from the perspective of faculty members?

Table (1): Means and standard deviations related to the personal values

\begin{tabular}{|l|l|l|l|l|l|}
\hline No. & Statement & Mean & Std. & Rank & Level \\
\hline 3 & Students provide attention to their general appearance & 3.55 & 0.80 & 1 & Moderate \\
\hline 12 & $\begin{array}{l}\text { Students have the capability to make a positive change to } \\
\text { themselves }\end{array}$ & 3.52 & 0.76 & 2 & Moderate \\
\hline 1 & Students are elegant & 3.52 & 0.78 & 2 & Moderate \\
\hline 2 & Students provide attention to personal hygiene & 3.51 & 0.78 & 4 & Moderate \\
\hline 4 & Students have a high self-confidence level & 3.49 & 0.65 & 5 & Moderate \\
\hline 10 & $\begin{array}{l}\text { Students deal positively with the constructive criticism made } \\
\text { by instructors }\end{array}$ & 3.48 & 0.74 & 6 & Moderate \\
\hline 17 & Students smile to others & 3.37 & 0.81 & 7 & Moderate \\
\hline 16 & Students show respect to others & 3.35 & 0.72 & 8 & Moderate \\
\hline 5 & Students have inner balance & 3.31 & 0.76 & 9 & Moderate \\
\hline 7 & Students show respect to multiculturalism & 3.29 & 0.82 & 10 & Moderate \\
\hline 13 & Students are diligent & 3.27 & 0.78 & 11 & Moderate \\
\hline 6 & Students rely on themselves & 3.27 & 0.83 & 11 & Moderate \\
\hline 11 & $\begin{array}{l}\text { Students deal positively with the constructive criticism made } \\
\text { by colleagues }\end{array}$ & 3.26 & 0.79 & 13 & Moderate \\
\hline 8 & Students show respect to the one having a different opinion & 3.18 & 0.77 & 14 & Moderate \\
\hline 9 & $\begin{array}{l}\text { Students show much flexibility in terms of accepting the } \\
\text { opinion that contradicts one's opinion }\end{array}$ & 3.17 & 0.88 & 15 & Moderate \\
\hline 15 & Students have a high self-control level & 3.17 & 0.81 & 15 & Moderate \\
\hline 14 & Students reject intellectual rigidity & 3.15 & 0.80 & 17 & Moderate \\
\hline & Total & 3.34 & 0.50 & - & Moderate \\
\hline
\end{tabular}

Table (1) presents the means and standard deviations related to personal values. It can be noticed that the extent of adopting personal values by respondents is moderate. That is because the total mean is 3.34 . This result is consistent with the result concluded by Al-Jalad (2008), and Al-Makhzoumi (2008). All the items related to personal values show a moderate mean. The means of table (1) are within the range of 3.15-3.55. The standard deviations in table (1) are within the range of 0.65-0.88.

The mean of item (3) is ranked first and considered moderate. It is (3.55). It states the following: (Students provide attention to their general appearance). The latter result is attributed to the poor financial situation of students' families. That shall hinder students from getting the things needed for taking care of their general appearance. In addition, university students aren't ready yet to get a job that enable them to get things needed for taking care of their general appearance. Thus, that shall hinder students from taking care of their general appearance. The mean of statement (14) is ranked last and considered moderate. It is 3.15. The latter statement states the following: (Students reject intellectual rigidity). The latter result may be attributed to the fact that students do not accept having a discussion about anything that contradicts their beliefs, and principles. 
Table (2): Means and standard deviations related to the affective values

\begin{tabular}{|l|l|l|l|l|l|}
\hline No. & Statement & Mean & Std. & Rank & Level \\
\hline 27 & Students deal with others in a positive manner & 3.57 & 0.75 & 1 & Moderate \\
\hline 31 & Students believe that it's necessary to protect the beauty of nature & 3.30 & 0.83 & 2 & Moderate \\
\hline 28 & $\begin{array}{l}\text { Students provide attention to the aesthetic aspects of their dialogue. } \\
\text { Thus, they use beautiful words when talking }\end{array}$ & 3.28 & 0.68 & 3 & Moderate \\
\hline 34 & Students can differentiate between beautiful and unbeautiful things & 3.27 & 0.78 & 4 & Moderate \\
\hline 35 & Students have a good taste & 3.26 & 0.79 & 5 & Moderate \\
\hline 32 & Students are sensitive & 3.24 & 0.70 & 6 & Moderate \\
\hline 29 & Students are honest in their feelings & 3.24 & 0.80 & 6 & Moderate \\
\hline 36 & Students can realize the beauty of musical works of art & 3.23 & 0.87 & 8 & Moderate \\
\hline 33 & Students can meditate well & 3.18 & 0.79 & 9 & Moderate \\
\hline 30 & Students can see the beauty of this universe & 3.16 & 0.81 & 10 & Moderate \\
\hline 37 & $\begin{array}{l}\text { Students is aware of the significance of the beauty of the Arab } \\
\text { works of art }\end{array}$ & 3.15 & 0.91 & 11 & Moderate \\
\hline 38 & $\begin{array}{l}\text { Students is aware of the significance of the beauty of the global } \\
\text { works of art }\end{array}$ & 3.07 & 0.80 & 12 & Moderate \\
\hline & Total & 3.25 & 0.55 & & Moderate \\
\hline
\end{tabular}

Table (2) presents the means and standard deviations related to affective values. It can be noticed that the extent of adopting affective values by respondents is moderate. That is because the total mean is 3.25 . This result is consistent with the result concluded by Al-Omari (2015). The means in table 2 are within the range of 3.073.57. The standard deviations in table (2) are within the range of $0.68-0.91$. The mean of statement 27 is ranked first and considered moderate. It is 3.57. The latter statement states the following (Students deal with others in a positive manner). That may be attributed to having differences between students in each course in terms of the extent of possessing knowledge. These differences are attributed to having differences between students in terms of major and academic year. These differences lead to having jealousy between students. Such jealousy shall not make students deal positively with each other.

The mean of statement 38 is ranked last and considered moderate. It is 3.07. The latter statement states the following: (Students is aware of the significance of the beauty of the global works of art). Despite that, students realize the significance of being open to global cultures through gaining knowledge about the works of art of these cultures. Through gaining such knowledge, students shall develop themselves in affective aspects.

Table (3): Means and standard deviations related to the social values

\begin{tabular}{|l|l|l|l|l|l|}
\hline No. & Statement & Mean & Std. & Rank & Level \\
\hline 39 & Students have a sense of brotherhood & 3.56 & 0.78 & 1 & Moderate \\
\hline 44 & Students realize the significance of group work & 3.47 & 0.78 & 2 & Moderate \\
\hline 40 & Students have a sense of cooperation & 3.46 & 0.81 & 3 & Moderate \\
\hline 43 & Students deal with others positively & 3.38 & 0.77 & 4 & Moderate \\
\hline 42 & Students respect others' rights & 3.31 & 0.78 & 5 & Moderate \\
\hline 41 & Students refrain from committing negative practices & 3.28 & 0.79 & 6 & Moderate \\
\hline 47 & Students are proud of their heritage & 3.26 & 0.76 & 7 & Moderate \\
\hline 46 & Students preserve public places & 3.18 & 0.75 & 8 & Moderate \\
\hline 45 & Students are aware about the changes that occurred to society & 3.18 & 0.79 & 9 & Moderate \\
\hline & & 3.34 & 0.54 & & Moderate \\
\hline
\end{tabular}

Table (3) presents the means and standard deviations related to social values. It can be noticed that the extent of adopting social values by respondents is moderate. That is because the total mean is 3.34 . This result is consistent with the result concluded by Al-Shaheen (2010), and Al-Kharabsheh (2007). . The means in table 2 are within the range of 3.18-3.56. The mean of statement 39 is ranked first and considered moderate. It is 3.56 . The latter statement states the following: (Students have a sense of brotherhood). The latter result may be attributed to the spread of favoritism and the increasing levels of loyalty to clan. It may be attributed to the spread of compliments among students. These things weaken the sense of brotherhood within students.

The mean of statement 45 is ranked last and considered moderate. It is 3.18 . The latter statement states the following: (Students are aware about the changes that occurred to society). The latter result may be attributed to the poor capabilities of students to analyze the rapid changes. Such poor capabilities make students confused.

In the light of the aforementioned information, it was found that the extent of adopting aesthetic values by the students enrolled in Jordanian universities is moderate from the perspective of faculty members. That means that additional efforts must be exerted by decision makers and educators in order to promote aesthetic values among students in Jordanian universities. 


\section{Results and Discussion related to the second question:}

The second question:

Q.2. What is the extent of doing good behaviors by the students enrolled in Jordanian universities from the perspective of faculty members?

Table (4): Means and standard deviations related to the behavioral aspect

\begin{tabular}{|l|l|l|l|l|l|}
\hline No. & Statement & Mean & Std. & Rank & Level \\
\hline 1 & $\begin{array}{l}\text { Students seek complying with the rules of etiquette when dealing } \\
\text { socially with their instructors }\end{array}$ & 3.63 & 0.72 & 1 & Moderate \\
\hline 2 & $\begin{array}{l}\text { Students seek complying with the rules of etiquette when dealing } \\
\text { socially with their colleagues }\end{array}$ & 3.40 & 0.75 & 2 & Moderate \\
\hline 3 & Students avoid using bad and insulting words & 3.17 & 0.85 & 3 & Moderate \\
\hline 4 & Students seek keeping the university clean and beautiful & 2.86 & 0.98 & 4 & Moderate \\
\hline 5 & Students seek making the lecture halls beautiful & 2.73 & 0.89 & 5 & Moderate \\
\hline 6 & $\begin{array}{l}\text { Students are concerned in keeping the facilities of the university clean } \\
\text { and beautiful }\end{array}$ & 2.73 & 0.97 & 5 & Moderate \\
\hline 9 & Students are concerned in reducing the noise made in the university & 2.48 & 1.00 & 7 & Moderate \\
\hline 8 & $\begin{array}{l}\text { Students are concerned in keeping the walls of university clean from } \\
\text { any writing }\end{array}$ & 2.47 & 1.07 & 8 & Moderate \\
\hline 7 & Students are concerned in keeping the university bathrooms clean & 2.44 & 1.10 & 9 & Moderate \\
\hline & Total & 2.88 & 0.68 & & Moderate \\
\hline
\end{tabular}

Table (4) presents the means and standard deviations related to students' behavioral values. It can be noticed that the extent of adopting these values by respondents is moderate. That is because the total mean is 2.88. The latter result is consistent with the result concluded by Al-Tal (2017), Darwazeh (2013), and Ahmad (2011). It can be noticed that the means are within the range of 2.44-3.63. The standard deviations are within the range of $0.72-1.10$. The mean of statement 18 is ranked first and considered moderate. The latter statement states the following: (Students seek complying with the rules of etiquette when dealing socially with their instructors). This result may be attributed to being incapable to communicate with others. It may be attributed to having wrong beliefs that are related to first impression. It may be attributed to stereotyping others. Stereotyping others shall hinder students from complying with the rules of etiquette when dealing socially with their instructors. Despite that, students exert effort to be liked by their instructors. They expert effort to make their instructors satisfied. Such efforts are exerted by students to get high scores. The mean of statement 7 is ranked last and considered moderate. It is 2.44. The latter statement states the following: (Students are concerned in keeping the university bathrooms clean). The latter results may be attributed to the students' poor loyalty to their university. It indicates that students believe that cleaning the university is the responsibility of staff responsible for cleaning.

In the light of the aforementioned information, it was found that the extent of doing good behaviors by the students enrolled in Jordanian universities is moderate from the perspective of faculty members. That means that additional efforts must be exerted by decision makers and educators in order to promote good behaviors among students in Jordanian universities.

\section{Results and Discussion related to the third question}

Q.3. What is the extent of capability to predict the behaviors of the students enrolled in Jordanian universities through their aesthetic values?

Table (5): The extent of capability to predict the behaviors of the students enrolled in Jordanian universities through their aesthetic values

\begin{tabular}{|l|l|l|l|l|}
\hline Independent variable & Correlation coefficient value (R) & Coefficient of determination & F value & Sig. \\
\hline Personal values & 0.84 & 0.68 & $253.16 \mathrm{q}$ & 0.00 \\
\cline { 1 - 1 } & & & & \\
\cline { 1 - 4 } Social values & & & & \\
\hline
\end{tabular}

Based on table (5), it can be noticed that the correlation coefficient value is 0.84 . That means that there is a strong correlative relationship between the aesthetic values and the behaviors of the students enrolled in Jordanian universities. The value of the total sum of squares is 0.68 . That means that $68 \%$ of the changes in the students' behaviors are attributed to aesthetic values in personal, affective and social areas. Based on table (5), the $F$ value is 253.16 and the significance value is 0.000 . The latter value is less than the statistical significance level of 0.05 . That means that the behaviors of the students enrolled in Jordanian universities can be significantly predicted through their aesthetic values. It means that the independent variable has a significant impact on the dependent variable.

In the light of the aforementioned information, there is a need to conduct studies about aesthetic values and exert effort to promote these values. That is needed due to the significant impact of these values on people's 
behaviors and practices. In addition, Jordanian universities must exert effort to promote these values among students. For instance, they should encourage students to take care of their general appearance, and personal hygiene. They should raise the self-confidence level of students. Raising this level shall positively affect the way students deal with others. In addition, universities must provide students with opportunities to interact with their colleagues, other university students and the university staff. They must engage students in workshops and training courses for developing them. Engagement in trips students in trips which shall promote collaboration among students. It shall promote loyalty to state and enrich students' knowledge about their nation, heritage, and civilization. It should be noted that promoting aesthetic values among students shall positively affect students' behaviors. For instance, it shall encourage students to preserve the university facilities and tangible resources that shall be used by the future generations.

\section{Conclusion}

It was found that the extent of adopting aesthetic values by the students enrolled in Jordanian universities is moderate from the perspective of faculty members. It was found that the extent of doing good behaviors by the students enrolled in Jordanian universities is moderate from the perspective of faculty members. That means that additional efforts must be exerted by decision makers and educators in order to promote good behaviors and aesthetic values among students in Jordanian universities. It was found that there is a strong correlative relationship between the aesthetic values and the behaviors of the students enrolled in Jordanian universities. That is because the correlative coefficient value is 0.84 and the value of the total sum of squares is 0.68 . That means that $68 \%$ of the changes in the students' behaviors are attributed to the aesthetic values. That means that the behaviors of the students enrolled in Jordanian universities can be significantly predicted through their aesthetic values. In the light of the aforementioned results and studies, it can be concluded aesthetic education plays a significant role in developing students in various aspects. Therefore, more attention must be given to aesthetic education in universities. For instance, faculty members must encourage university students to see and explore beauty in works of art and nature. In addition, the developers of university curricula must seek promoting aesthetic values through curricula

\section{Recommendations and suggestions}

In the light of the aforementioned results, the researchers recommend:

- Carrying out suitable educational measures and developing policies in the aim of promoting aesthetic values among the students enrolled in Jordanian universities.

- Providing attention by academic leaders to the behaviors and values that are prevalent among students. Those leaders must encourage researchers to conduct studies about the psychological, social and economic problems that university students suffer from. Those leaders must encourage researchers to conduct studies about students' reality

- Developing the moral and financial incentives systems of students, and rewarding the students who make distinguished achievements and exert much effort. The university management must promote loyalty among students to their university and country. It must promote ethical and religious values among students. Furthermore, the relationship between the university and students must be based on trust, \& love.

- Conducting more studies about aesthetic values and exploring their relationship with other variables.

\section{References}

Abu Al-Hayjah, Abed Al-Raheem Awad (2008). Aesthetic and educational values. Amman. Yafa Al-Elmeye publication and distribution house.

Abu Naser, Sameeha Mohammad Mahmoud (1996). The aesthetic values of the students enrolled at the faculty of Qualitative education in Egypt: A field study. PhD dissertation. Mansoura University. Egypt.

Abu Zeid, Mariam Ahmad and Al-Zyood, Mohammad Sayel (2007). Educational values among secondary school students in Amman governate as perceived by the students themselves. Dirasat Journal for Educational Sciences. Vol. 34, pp. 735-765

Ahmad, Abed Al-Baqi (2011). The behavioral problems of the students enrolled in the University of Khartoum and their relationship with some variables. Unpublished MA thesis. University of Khartoum, Sudan.

Al- Omari, Nawal Saleh (2010). The role of intermediate school in promoting aesthetic values among the female intermediate school students from the female teachers' perspective: A field study. Unpublished MA thesis. King Saud University. Reyad. Saudi Arabia

Al-Aisy, Ali bin Masoud bin Ahamd (2008). Promotion of ethical values among intermediate school students from the Islamic education teachers' perspective in Al-Qanfatha. Unpublished MA thesis. Um AlQurah University. Saudi Arabia

Al-Dwairi, Fayez (2007). The role of public universities in promoting national security. Unpublished PhD 
dissertation. University of Jordan. Amman. Jordan

Al-Emyan, Mahmoud (2002). Organizational behavior in business organizations. Amman. Wa'el publication and distribution house.

Al-Hammad, A \& Al-Qudah, M. (2019). Role of Jordanian Universities in Educating Students on Entrepreneurship from the Point of View of Juggling Students, An Interdisciplinary Journal for Science and Technology Studies, 13(1): 167-180

Al-Harbi, Musa'ed Dayf Allah (2018). The educational values adopted by the students enrolled at Majmaah University in the Kingdom of Saudi Arabia. The International Journal of Educational Research (a journal for the United Arab Emirates University), 42(2), 239-265

Al-Jahni, Hanan Ateye (2003). Promoting aesthetic values among the primary female school students from an Islamic perspective. Unpublished $\mathrm{PhD}$ dissertation. The college of education for girls. Reyad. Saudi Arabia

Al-Jallad, Majed (2008). The values adopted by the students enrolled at Ajman University for science and technology in accordance with some variables. Um Al-Qurra University Journal for Educational and Psychological Sciences. 20(2). 367-430

Al-Jallad, Majed Zaki (2005). Learning and teaching values: The methods and strategies of teaching values from theoretical and empirical perspectives. $1^{\text {st }}$ edition. Amman. Al-Maseera publication and distribution house.

Al-Kharabsheh, Omar (2007). The extent of adopting educational values by the female students enrolled at Princess Alia University College. The Journal of Educational and Psychological Sciences 8(3), pp. 190220

Al-Makhzoumi, Naser (2008). The values adopted by the students enrolled at Zarqa Private University. The Journal of Damascus University. 24(2), 359-397

Al-Omari, Asma' Abed Al-Men'em (2015). The extent of adopting values by the students enrolled in Jordanian universities from the perspective of the students' themselves. Dirasat Journal for Educational Sciences. 42(3). 168-177

Al-Qudah, M (2006). The Relationship between Family Socialization Patterns and Some Personality Attributes of Female Undergraduates at Mu'tah University, Jordan Journal of Educational Sciences, 2(3): 155-168.

Al-Qudah, M (2017). The Extent University of Jordan Students Represent Islamic Values from Their Perspective, Dirasat: Educational Sciences,44(4), 9: 257-275.

Al-Qudah, M\& Al-Zboon, M. S. \& Al-Ashqar, A. A(2016). The Degree of Resistance to Temptation among the Students of the University of Jordan and its Relationship to the Pattern of Family Upbringing, European Journal of Social Sciences 52(3): 280-29

Al-Qudah, M, Hindi. M (2019). Environmental values included in Science Books

Al-Shahin, Ghanem (2010). The extent of influence of social, economic and religious values on the attitudes of female student teachers at the teacher development institution towards the teaching profession. The Journal of Educational and Psychological Sciences. 11(2), 154-178

Al-Shloul, Ashraf (2007). The prevalent aesthetic values among the students enrolled at the faculties of education, fine arts, and economy at Yarmouk University. Unpublished $\mathrm{PhD}$ dissertation. Irbid. Jordan

Al-Tal, Wa'el (2017). Academic development of university students in the light of the high performance indicators. The Jordanian Journal of Educational Sciences. 13(4), pp.449-458

Al-Tamimi, A \& Al-Qudah, M.A (2019) The Relationship between the parenting Styles of the Students of the First Three Grades with their Level of Creativity, An Interdisciplinary Journal for Science and technology Studies, (13)01: 123-134

Al-Turk. R, Al-Qudah, M. (2017). The Jordanian Universities Students Practicing Degree of Thinking Skills, Dirasat: Educational Sciences, 44(4),6: 73-91

Asayesh, M.\& Bahramizadeh, H. (2011). Examination of personal values system and its changes among young people. Procedia - Social and Behavioral Sciences, 30, 1390- 1394.

Bakoush, Al-Jmou'y Mu'men (2017). Social change and its impact on university students' social values: A field study targeting Algerian universities. PhD dissertation. University of Biskra, Biskra, Algeria

Ben Tarif, E \& Al-Qudah, M. (2019). International Journal of Advanced Science and Technology The Reality about the Educational Capabilities of the Jordanian Women in preventing their Sons / Daughters from Adopting Fanatical Ideologies, Journal of Advanced Science 13(4):214-227

Bukhari, Adel bin Saeed (2006). Aesthetic education under the Islamic ideology and some western ideologies: A comparative study. Unpublished MA thesis. Um Al-Qurra University. Makkah. Saudi Arabia

Darwazeh, Afnan (2013). Training on practicing self-control during learning and its impact on academic achievement in university. The Association of Arab Universities Journal for Research in Higher Education. 33(4), pp.17-36 
Denac, O., Čagran, B., Denac, J., \& Sicherl Kafol, B. (2011). Arts and Cultural Education in Slovenian Primary Schools. The New Educational Review, 24, 121-132.

Denac, O. (2014) The Significance and Role of Aesthetic Education in Schooling. Creative Education, Vol. 5 1714-1719

Ejbarh, T \& Al-Qudah. (2018) The Role of Libyan Universities in the Developing Students'

for the 10th Grade in Jordan "An Analytical Study", An Interdisciplinary Journal for Science and Technology Studies, 13(1): 135-144.

Hammadneh, O \& Al-Qudah. (2017) .A Proposed Educational Role to The Jordanian Public Universities to Improve Their Students' Values, Dirasat: Educational Sciences, (44)4, 1: 185-203.

Hanel, P. (2016). Human values and value instantiations: Similarities and differences between countries and their implications. A dissertation of Doctor of Philosophy. School of Psychology, Cardiff University.

Hatahet. F \&Alquda, M. (2016). Family Problems Experienced by Students of the University of Jordan, European Scientific Journal (12)13: 145-156

Heilat, M \& Al-Qudah, M\&\& AL-Rbabaah, J. (2008) The relationship between family socialization patterns and emotional disturbance among 6th grade male students, Association of Arab Universities Journal for Education and Psychology, 1(6): 1-34.

Jardim, M., da Silva Junior, G., Alves, M., de Gouveia, B. \& Silva, R. B. (2018). The ethics and the meaning of life among college students. International Journal of Clinical Medicine, 9(04), 221-233.

Kroflič, R. (2007). Educational Value of Aesthetic Experience. Sodobnapedagogika, 3, 12-30.

Lawless H.T., and Heymann H. (1999) Descriptive Analysis. In: Sensory Evaluation of Food. Food science text series. Springer, Boston, MA

Malkawi, S \&Al-Qudah, M. $(2018,1)$. Reality and Obstacles of the Partnership between Family and School in Jordan, Modern Applied Science, 2(12), 81-92.

Malkawi, S \&Al-Qudah, M. (2018, 2). The Reality of Partnership Between The Family and The School from The Perspective of Teachers' Working in Irbid First Education Directorate, Dirasat: Educational Sciences 45(3): 209-225.

Mercader, V. (2006). Study of the ethical values of college students. A dissertation of Doctor of Education, College of Education, University of South Florida.

Orsinger, A. K. (2014). Developing democratic civic virtues through aesthetic education and design in public Schools. A dissertation of Doctor of Philosophy. Faculty, The University of Texas at Austin.

Sameh, Fawzi (2017). Citizenship. $1^{\text {st }}$ edition. Cairo. Cairo Center for studies about human rights

Sharma, K. (2015). A Comparative study of aesthetic, economic and political values of undergraduate students. The International Journal of Indian Psychology, 2(2), 42-55.

Sheler, Fredresh (1991). Aesthetic education for human. Translated by Wafa' Ibrahim. Cairo. The General Egyptian Book Organization.

Thinking Skills, The Arab Journal for Quality Assurance in Higher Education, 11(35): 103-122.

Trstenjak, A. (1981). Psychological Creativity. Ljubljana: Slovenskamatica.

Zaman, F. and Muhammad, N. (2012). A comparative study of the values of Bangladeshi male students in public and private universities. ASA University Review, 6(1), 33-42

Zamel, Majdi Ali (2015). Teachers' attitudes towards the educational values adopted by secondary school students in Nables and methods for promoting such values. Hebron University Journal. 10(1), pp. 153182

Acknowledgment

The researchers would like to thank the University of Jordan for providing them with support 